O.K. Farat, E.V. Zaliznaya, S.A. Varenichenko, V.I. Markov

\title{
REARRANGEMENT OF SUBSTITUTED PYRIMIDIN-4-ONES UNDER THE VILSMEIER-HAACK REACTION
}

\author{
Ukrainian State University of Chemical Technology, Dnipro, Ukraine
}

\begin{abstract}
The article describes the result of our study on rearrangements of four heterocyclic systems with variation of oxygen and nitrogen atoms, in particular, the results of formylation of 2,2-disubstituted hydroquinazolones under the conditions of the Vilsmeier-Haack reaction. A new rearrangement of spiro derivatives of quinazolin-4 $(3 \mathrm{H})$-ones was discovered under the action of a formylating reagent with the formation of predicted 1-cyclohex(pent)-1en-1-ylchinazolin-4- $(1 \mathrm{H})$-ones. The absence of this rearrangement for 2,2-dimethyl-2,3dihydroquinazolin-4(1H)-one is explained. 6',7',7'-Trimethyl-1',5',6',7'-tetrahydrospiro [cyclohexane-1,2'-pyrrolo[3,4-d]pyrimidine]-4' $\left(3^{\prime \prime} \mathrm{H}\right)$-one is a structural analogue of spiro derivatives of quinazolin-4 $(3 \mathrm{H})$-ones; it undergoes a similar rearrangement with the formation of 1-cyclopent-1-en-1-yl-6,7,7-trimethyl-1,5,6,7-tetrahydro-4H-pyrrolo[3,4d]pyrimidin-4-one when interacting with Vilsmeier-Haack reagent.
\end{abstract}

Keywords: hydroquinazolones, rearrangement, Vilsmeier-Haack reagent, imidoyl chloride, crystal structure.

DOI: $10.32434 / 0321-4095-2021-134-1-101-109$

\section{Introduction}

Griess was the first who reported the synthesis of hydrogenated quinazolones in 1869 [1]. Since then, this direction has been actively developing. In the first place, the interest in this class of compounds is due to their practical importance as physiologically active compounds; in the second place, these substances can be used for the construction of the quinazolone system in the context of the principles of green chemistry [2].

Our interest in this class of compounds is caused by the presence of the cyclic heminal diazo group $(\mathrm{N}-\mathrm{C}-\mathrm{N})$ in the skeleton of the quinazolone molecular platform, one nitrogen atom of which belongs to the amide group (Scheme 1).<smiles>[R]C1([R])NC(=O)c2ccccc2N1</smiles>

Scheme 1

Our previous works [3-7] showed that similar systems, depending on the atomic composition of the heminal system and the saturation of the annelated cycle, behaved differently under the Vilsmeier-Haack reaction conditions. Thus, during the formylation of a spiro compound 1 with a chloroiminium salt in DMF, an extensive

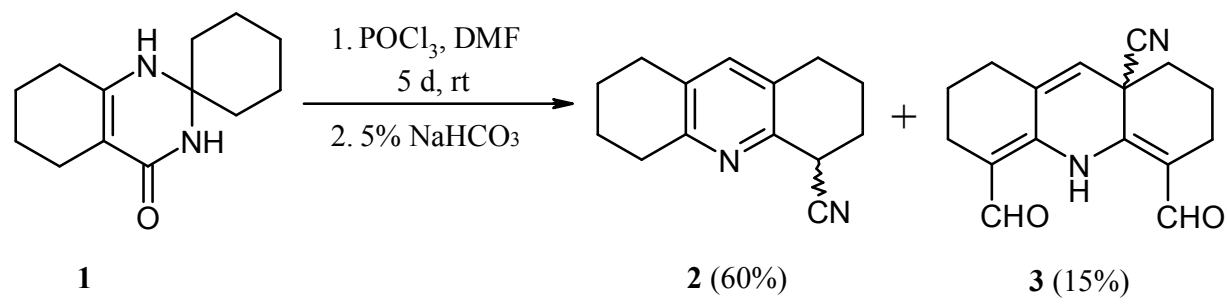

Scheme 2

(c) O.K. Farat, E.V. Zaliznaya, S.A. Varenichenko, V.I. Markov, 2021 
rearrangement of the carbon skeleton occurred with the formation of acridine derivatives 2 and 3 (Scheme 2) [3].

Under the conditions of the Vilsmeier-Haack reaction, 1,3- and 3,1-benz(naphth)oxazines derivatives behaved interestingly. The treatment of 1,3-benz(naphth)oxazines derivatives 4 with the Vilsmeier-Haack reagent at elevated temperatures led to recyclization with the formation of previously unknown substituted (benzo)xanthenes 5 (Scheme 3) [4,5].

Compounds 5 are good building blocks for constructing dyes with high extinction coefficients [6], they can also be fluorophores [7]. Similar xanthene dyes are widely used as contrast agents for biomedical imaging [8,9], optical fibers, filters, etc. [10].

The interaction of 3,1-benzoxazines 6 with 1 equivalent of Vilsmeier reagent at room temperature for 0.5 hour led to the quantitative yield of acridones 7. An increase both in the reaction time up to one hour and in the content of formylating agent to a 3 -fold molar excess led to the production of acridines 8 (Scheme 4) [4]. Formylation of compounds 7 led to their chlorination with the formation of acridines 8 .

This work was aimed at studying the formylation of 2,2-disubstituted hydroquinazolones under the conditions of the Vilsmeier-Haack reaction.

\section{Results and discussion}

Formylation of compound 9 under the conditions of the Vilsmeier-Haack reaction yielded compound 10, which was formed as a result of the opening of the pyrimidine cycle with further formylation of the intermediate (Scheme 5).

The structure of compound 10 was established using ${ }^{1} \mathrm{H}$ NMR spectroscopy and mass spectrometry. There is a peak of molecular ions with $m / z 259$ [M] ${ }^{+}$ $(35 \%)$ in the mass spectrum with electron ionization.

According to the ${ }^{1} \mathrm{H}$ NMR spectrum of compound 10 recorded in $\mathrm{CDCl}_{3}$, the hydrogen atom of the aldehyde group appears as a doublet at $9.96 \mathrm{ppm}$ $\left(\mathrm{SSCC}^{3} J=7.0 \mathrm{~Hz}\right.$ ) and the signal of the neighboring $\mathrm{CH}$ group has a chemical shift of $6.77 \mathrm{ppm}$ (SSCC ${ }^{3} \mathrm{~J}=7.0 \mathrm{~Hz}$ ). The hydrogen atom of $\mathrm{NH}$, due to conjugation with the aldehyde group and the formation of hydrogen bond with the oxygen atom of the aldehyde group, is strongly de-screened and<smiles>[R]c1c2c(cc3c1C(=O)NC1(CCCC1)O3)[C]CC2</smiles>

4
1. $\mathrm{POCl}_{3}, \mathrm{DMF}, 0^{0} \mathrm{C}$,<smiles>O=[N+][O-]</smiles><smiles></smiles><smiles>O=[W]O[Na]</smiles><smiles></smiles>

Scheme 3

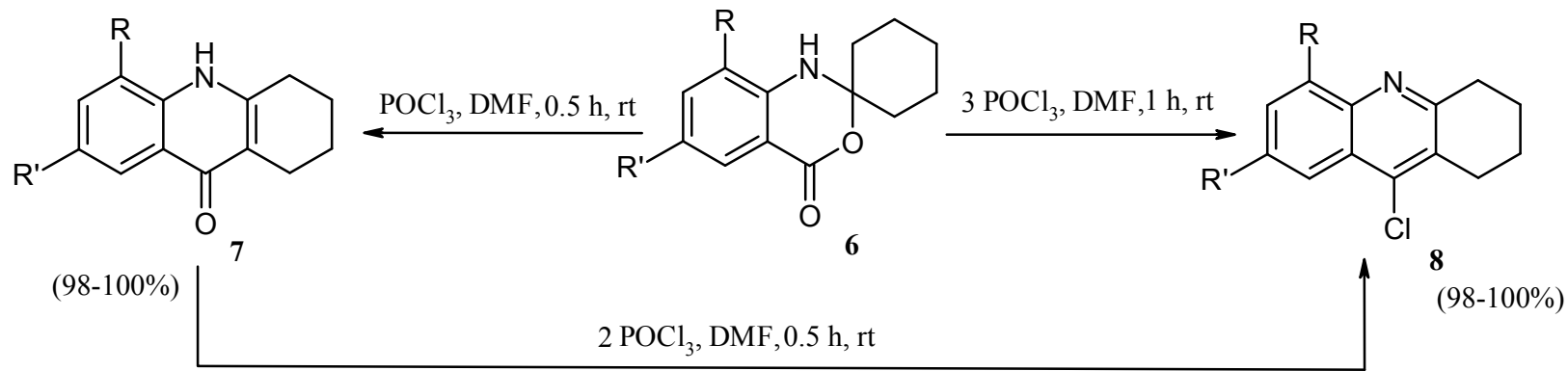

Scheme 4 
<smiles>CC1=CC=C[B]N1c1ccccc1C(=O)N=CN(C)C</smiles>

Scheme 5<smiles>C=C(C)Nc1ccc([C@H](C)C(=N)c2ccccc2[NH+]=C(C)C)cc1C(=N)Cl</smiles><smiles>C/C(=C/C=[N+](C)C)Nc1ccccc1/C(Cl)=N\C=[N+](C)C</smiles><smiles>CNC(=O)C=NC(=O)c1ccccc1N1C=CC=C(C)C1</smiles>

Scheme 6

resonates in the downfield region of the spectrum in the form of a singlet at $12.26 \mathrm{ppm}$. It is this signal that indicates the formation of the $\mathrm{Z}$-configuration of the enaminformyl fragment. Otherwise, the NH signal would not have had such a large chemical shift. The presence of a dimethylamidine fragment is evidenced by a singlet signal at $3.15 \mathrm{ppm}$, which corresponds to two methyl groups $\mathrm{NMe}_{2}$, and the $\mathrm{CH}$ signal of this fragment at $7.57 \mathrm{ppm}$ is in the form of a singlet. The hydrogen atoms of the methyl group near the double bond have a chemical shift of $2.53 \mathrm{ppm}$. Four aromatic hydrogen atoms resonate in the $6.82-8.20 \mathrm{ppm}$ range.

The mechanism of this interaction can be represented in the following way (Scheme 6). This scheme shows the boundary structures, which are shown to achieve greater clarity. At the first stage, when compound 9 interacts with the VilsmeierHaack reagent, an imidoyl chloride salt is formed, which opens at the $\mathrm{C}-\mathrm{N}^{+}$bond due to the neighboring nitrogen atom, and intermediate $\mathrm{A}$ is formed after the elimination of the proton. This intermediate is formylated with chloroiminium salts at two positions, yielding intermediate B, which forms the final product 10 after alkaline hydrolysis. Scheme 6 shows the boundary structures to explain why hydrolysis occurs in such a way that an amidine fragment remains near the amide group and hydrolysis occurs in the enamine fragment with the formation of an aldehyde group.

Boundary structures can be written for intermediate $\mathrm{B}$, in which the positive charge of the amidine moiety is stabilized by a chlorine atom (boundary structure C') and an aromatic system, 
especially by a nitrogen atom in the ortho-position (boundary structure C'). It is this charge distribution that leads to the hydrolysis of the imidoyl chloride and dimethylamine groups to form compound 10.

Imidoyl chloride 12 was isolated with a high yield by the interaction of spiran 11 with the Vilsmeier-Haack reagent for one day at room temperature, after neutralization with an ammonia solution (Scheme 7).

The structure of compound 12 was established using ${ }^{1} \mathrm{H}$ and ${ }^{13} \mathrm{C}$ NMR spectroscopy as well as mass spectrometry.

Compound 12 turned out to be unstable and it turned red after 2 days. After 4 days, it was tarred. In this regard, it was decided to establish what would happen to compound 12 when heated. Compound 12 was heated in an open crucible without solvent at $120^{\circ} \mathrm{C}$ for $20 \mathrm{~min}$. The result of this manipulation was the formation of anthranilic acid nitrile hydrochloride 13 with a high yield (Scheme 8).
The formation of anthranilic acid nitrile hydrochloride was proved by ${ }^{1} \mathrm{H}$ and ${ }^{13} \mathrm{C}$ NMR spectroscopy and mass spectrometry. It was obvious that the reaction proceeded through intermediate A, which was hydrolyzed by air moisture with the formation of compound 13 and cyclohexanone.

Expected substituted quinazolones 15 and 16 were synthesized by the treatment of compounds 11 and 14 with the Vilsmeier-Haack reagent at $40^{\circ} \mathrm{C}$ (Scheme 9).

The structures of compounds 15 and 16 were proved by using ${ }^{1} \mathrm{H}$ NMR spectroscopy and mass spectrometry. ${ }^{1} \mathrm{H}$ NMR spectra of these compounds recorded in DMSO revealed a characteristic signal of the hydrogen atom $\mathrm{CH}$ of the quinazolone ring in the form of a singlet at $8 \mathrm{ppm}$ and a signal of the alkene $\mathrm{CH}$ in the form of a multiplet with a chemical shift of $6 \mathrm{ppm}$. The spectrum of these compounds (ionization in the FAB) demonstrated peaks of protonated molecules with $100 \%$ intensity.<smiles>O=C1NC2(CCCCC2)Nc2ccccc21</smiles>

11

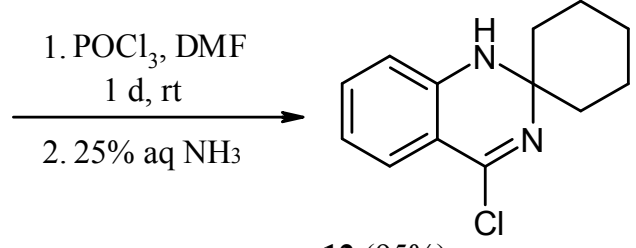

$12(95 \%)$

Scheme 7<smiles>N#Cc1ccc(O)cc1N=C1CCCCC1</smiles>

Scheme 8<smiles>NC(=O)c1ccc2c(c1)c(=O)ncn2C1=CCCC1</smiles>

$15-n=2(65 \%) ; 16-n=1(57 \%)$

Scheme 9 


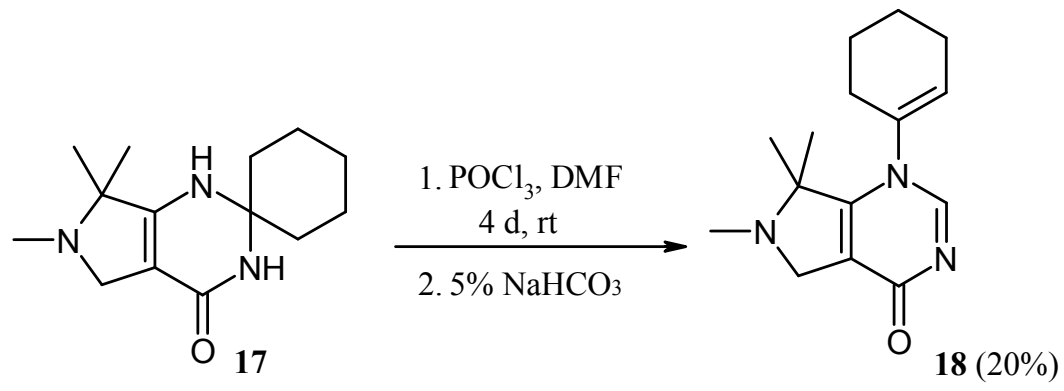

Scheme 10

The impossibility of migration of the double bond after the formation of imidoyl chloride in compound 17 made it structurally very similar to aromatic quinazolone 11. Formylation of compound 17 under the conditions of the Vilsmeier-Haack reaction at room temperature for 4 days resulted in the isolation of compound 18 with a low yield (Scheme 10). That is, the reaction proceeded similarly to the above (Scheme 9).

The structure of compound 18 was established using ${ }^{1} \mathrm{H}$ and ${ }^{13} \mathrm{C}$ NMR spectroscopy and mass spectrometry. Additionally, the DEPT-135 NMR experiments and $\mathrm{X}$-ray diffraction study were performed (Figure). In the ${ }^{1} \mathrm{H}$ NMR spectrum (in DMSO), the signals of the $\mathrm{CH}$ hydrogen atom of the quinazolone ring and the alkene $\mathrm{CH}$ in the form of a multiplet appeared at $8.11 \mathrm{ppm}$ and 6.08-6.13 ppm, respectively. In the ${ }^{13} \mathrm{C}$ NMR spectrum, these carbon atoms had chemical shifts of 151.3 and 131.1 ppm, respectively (chemical shift was determined using the DEPT-135 NMR experiment). The mass spectrum of compound 18 (ionization in the FAB) showed a peak of protonated molecules with $\mathrm{m} / z$ $260[\mathrm{M}+\mathrm{H}]^{+}(55 \%)$.

According to the data of the X-ray structural study, crystal 18 is a crystalline hydrate of the $1: 1$ composition. The cyclohexene substituent is deployed almost orthogonal with respect to the bicyclic fragment (torsion angle $\mathrm{C} 2-\mathrm{N} 2-\mathrm{C} 10-\mathrm{C} 11$ is 95.9(4) ${ }^{\circ}$ ) and is disordered in two configurations: twist bath $\mathrm{A}$ and $\mathrm{B}$ with a relative population of $0.66(1): 0.34(1)$. This value of the dihedral angle $\mathrm{C} 2-\mathrm{N} 2-\mathrm{C} 10-\mathrm{C} 11$ is caused by the interatomic repulsion of the hydrogen atoms of the methyl groups on one side, and the hydrogen atoms of the cyclohexene ring on the other side. The almost perpendicular arrangement of the quinazolone and cyclohexene rings explains the fact that the enamine fragment in compound 18 under the conditions of the Vilsmeier-Haack reaction is not formylated, since the lone pair of electrons of the nitrogen atom cannot conjugate with the double bond.

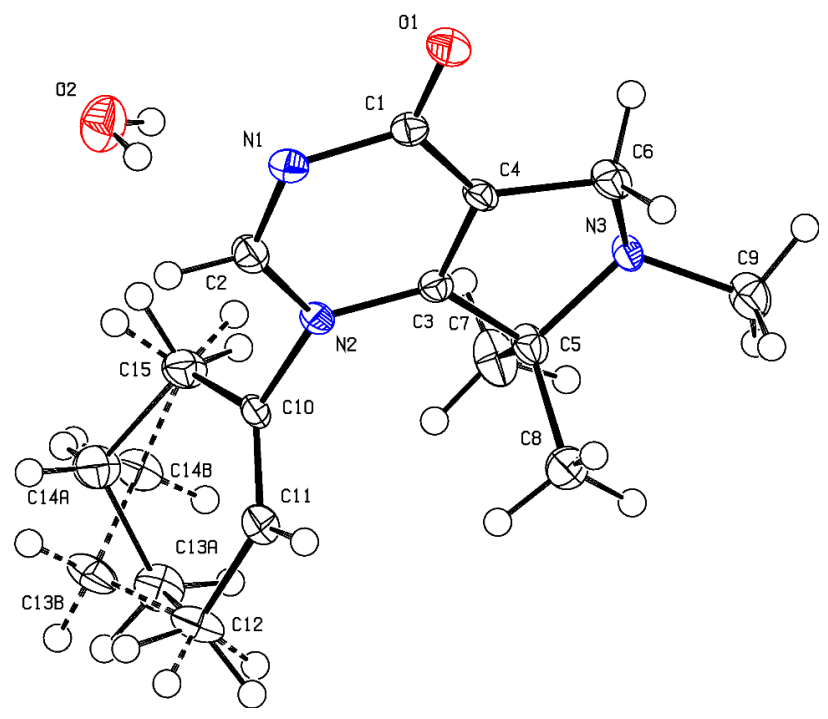

Molecular structure of compound 18 with atoms represented by thermal vibration ellipsoids of $50 \%$ probability

Most likely, the absence of formylation of the enamine fragment in compounds 15 and 16 is explained similarly. However, the repulsion of substituents occurs in them due to the hydrogen atoms of the aromatic and cyclohexene rings, albeit to a lesser extent.

Using the formation of compound 15 as an example, let us consider the conversion scheme of this reaction (Scheme 11). At the first stage of the interaction of the Vilsmeier-Haack reagent with compound 11, an imidoyl chloride salt is formed, which opens at the $\mathrm{CN}$ bond to intermediate $\mathrm{A}$. After proton cleavage and formylation at the nitrogen atom of imidoyl chloride, intermediate B is formed. Spatial proximity of the lone pair of electrons of the imine nitrogen atom and a positively charged amidine fragment lead to cyclization, and intermediate $\mathrm{C}$ is formed after transferring proton. When the reaction mixture is neutralized with a $\mathrm{NaHCO}_{3}$ solution, the groups are hydrolyzed to form the final product 15 . Analyzing the reaction scheme presented above 


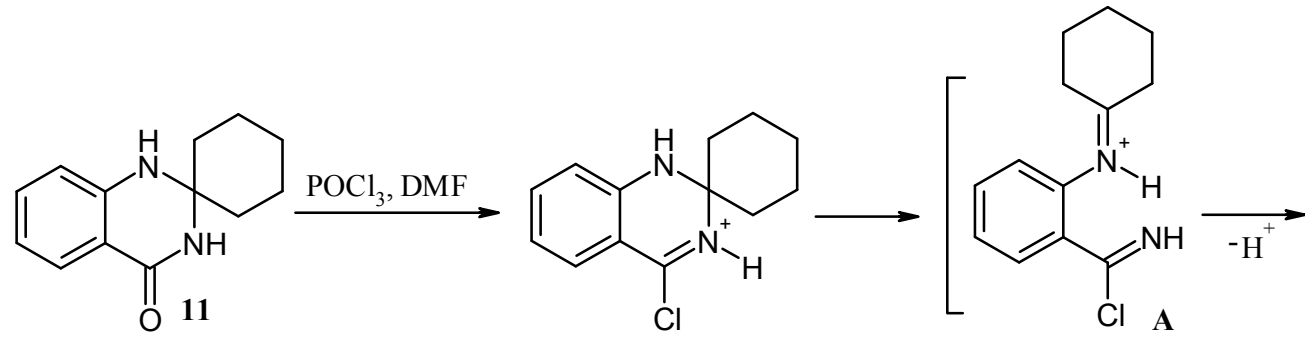<smiles>CN(C)C1N=C(Cl)c2ccccc2[N+]1=C1CCCCC1</smiles>

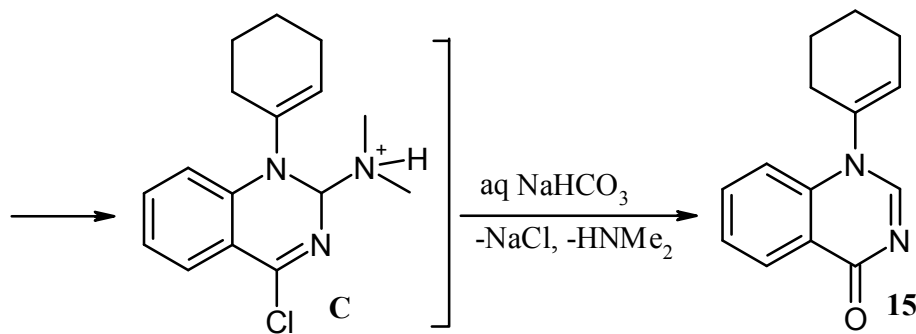

Scheme 11

(Scheme 11), the inertness of the enamine fragment with respect to the action of chlorinium salt has become even clearer. This is again due to the location of the cyclohexene ring relative to the bicyclic fragment. The repulsion between the hydrogen atoms of the cyclohexene ring and the dimethylamino group unfolds the cyclohexene ring from a planar arrangement with a bicyclic fragment, thereby breaking the conjugation between the lone pair of electrons of the nitrogen atom and the double bond.

\section{Conclusions}

When 1' $H$-spiro[cyclohexane-1,2'-quinazolin]$4^{\prime}\left(3^{\prime} H\right)$-one interacts with the Vilsmeier-Haack reagent at room temperature for one day, 4'-chloro1' $H$-spiro[cyclohexane-1,2'-quinazoline] is formed, which is transformed into anthranilic acid nitrile hydrochloride within 20 minutes at $120^{\circ} \mathrm{C}$. 1' $H$-Spiro[cyclohexane-1,2'-quinazolin]-4' (3' $H$ )-one in reaction with the Vilsmeier-Haack reagent at $40^{\circ} \mathrm{C}$ undergoes an electrophilic rearrangement with the formation of 1-cyclohex-1-en-1-ylquinazolin-4(1H)one. A similar rearrangement does not occur for 2,2dimethyl-2,3-dihydroquinazolin-4(1H)-one due to the possibility of the formylation of the enamine fragment, since the approach of the formylating agent to the alkenene fragment in its structure is not spatially hindered. After the formylation of this fragment, due to conjugation with an electron withdrawing group, the energy of the lone pair of electrons of the nitrogen atom is not sufficient for cyclization with the amidine fragment.

\section{Experimental section}

${ }^{1} \mathrm{H}$ and ${ }^{13} \mathrm{C}$ NMR spectra were acquired with the use of a Bruker Avance II 400 spectrometer (400.13 and $100.62 \mathrm{MHz}$, respectively) in DMSO$d_{6}$ DMSO- $d_{6} / \mathrm{CCl}_{4}$ or $\mathrm{CDCl}_{3}$ with TMS as internal standard. Mass spectra (EI ionization, $70 \mathrm{eV}$ ) were recorded by a MX1321 apparatus with direct sample injection at $200^{\circ} \mathrm{C}$ ionization chamber temperature. Mass spectra (FAB ionization) were registered by means of a VG-7070 spectrometer. Ion desorption from m-nitrobenzyl alcohol or thioglycerin was done by a beam of argon atoms with an energy of $8 \mathrm{keV}$. Elemental analysis was performed using a LECO CHN-900 Elemental analyzer. Melting points were determined in a Thiele tube. Monitoring of the reaction progress and assessment of the purity of synthesized compounds was done by TLC on 
Silicagel gel $60 \mathrm{~F}_{254}$ (Merck) plates, eluent $\mathrm{CHCl}_{3}-$ $i$-PrOH (10:1), visualization was performed in the iodine chamber. Compounds 9, 11 [11] and 17 [12] were synthesized by the method described in literature.

$N-[(1 \mathrm{E})-($ Dimethylamino)methylene $]-2-\{[(1 \mathrm{Z})-$ 1-methyl-3-oxoprop-1-en-1-yllamino\}benzamide (10)

The Vilsmeier-Haack reagent was prepared from $\mathrm{POCl}_{3}(1.55 \mathrm{~mL}, 0.017 \mathrm{~mol})$ and DMF $(4 \mathrm{~mL}$, $0.05 \mathrm{~mol})$ with ice-cooling. Compound 9 ( $1 \mathrm{~g}, 0.006$ mol) was added to the Vilsmeier-Haack reagent. The reaction mixture was stirred for $8 \mathrm{~h}$ and left for 5 days at room temperature. After that, the reaction mixture was poured onto ice, neutralized with a solution of soda to an alkaline medium. The precipitated solid of compound 10 was filtered off. Yield $0.7 \mathrm{~g}(45 \%), \mathrm{mp} 156-158^{\circ} \mathrm{C}$, white powder. ${ }^{1} \mathrm{H}$ NMR spectrum $\left(\mathrm{CDCl}_{3}\right), \delta$, ppm $(J, \mathrm{~Hz}): 12.26$ $(1 \mathrm{H}, \mathrm{s}, \mathrm{NH}) ; 9.92\left(1 \mathrm{H}, \mathrm{d},{ }^{3} J=7.0, \mathrm{CHO}\right) ; 8.20(1 \mathrm{H}$, $\left.\mathrm{d},{ }^{3} J=7.1, \mathrm{H} \mathrm{Ar}\right) ; 7.57(1 \mathrm{H}, \mathrm{s}, \mathrm{CH}), 7.39(1 \mathrm{H}, \mathrm{t}$, $\left.{ }^{3} J=7.3, \mathrm{H} \mathrm{Ar}\right) ; 7.13\left(1 \mathrm{H}, \mathrm{t},{ }^{3} J=7.6, \mathrm{H} \mathrm{Ar}\right) ; 6.82(1 \mathrm{H}$, $\left.\mathrm{d},{ }^{3} J=7.4, \mathrm{H} \mathrm{Ar}\right) ; 6.77\left(1 \mathrm{H}, \mathrm{d},{ }^{3} J=7.0, \mathrm{CH}\right) ; 3.15$ $(6 \mathrm{H}, \mathrm{s}, 2 \mathrm{Me}) ; 2.53(3 \mathrm{H}, \mathrm{s}, \mathrm{Me})$. MS (EI), $m / z\left(I_{\text {rel }}\right.$, \%): $259[\mathrm{M}]^{+}$(35). Found, \%: C 65.03; H 6.75; N 16.33. $\mathrm{C}_{14} \mathrm{H}_{17} \mathrm{~N}_{3} \mathrm{O}_{2}$. Calculated, \%: C 64.85; H 6.61; N 16.21.

4'-Chloro-1 $1 \mathrm{H}$-spiro[cyclohexane-1,2'quinazoline] (12)

The Vilsmeier reagent was prepared from $\mathrm{POCl}_{3}$ $1.55 \mathrm{~mL}(0.017 \mathrm{~mol})$ and DMF $4 \mathrm{ml}(0.05 \mathrm{~mol})$ with ice cooling. Compound $111.3 \mathrm{~g}(0.006 \mathrm{~mol})$ was added to the Vilsmeier reagent. The reaction mixture was left to stand at room temperature for 24 $\mathrm{h}$. The reaction mixture was poured on ice and treated with aq ammonia, the obtained solid was filtered off and dried to give product 12 . Yield $1.3 \mathrm{~g}(95 \%), \mathrm{mp}$ $75-77^{\circ} \mathrm{C}$ (mp $\left.75-77^{\circ} \mathrm{C}[14]\right)$, yellow powder. ${ }^{1} \mathrm{H}$ NMR spectrum (DMSO- $\left.d_{6}\right), \delta, \operatorname{ppm}(J, \mathrm{~Hz}): 7.31$ $\left(1 \mathrm{H}, \mathrm{d},{ }^{3} J=7.8, \mathrm{H} \mathrm{Ar}\right) ; 7.20\left(1 \mathrm{H}, \mathrm{t},{ }^{3} J=7.3, \mathrm{H} \mathrm{Ar}\right)$; $6.67\left(1 \mathrm{H}, \mathrm{d},{ }^{3} J=7.8, \mathrm{H} \mathrm{Ar}\right) ; 6.57\left(1 \mathrm{H}, \mathrm{t},{ }^{3} J=7.3, \mathrm{H}\right.$ $\mathrm{Ar}) ; 6.50(1 \mathrm{H}, \mathrm{s}, \mathrm{NH}) ; 1.78-1.86(2 \mathrm{H}, \mathrm{m}, \mathrm{spiro})$; 1.45-1.63 (8H, m, spiro). ${ }^{13} \mathrm{C}$ NMR spectrum $\left(\mathrm{DMSO}-d_{6}\right) \mathrm{d}$, ppm: $151.0 ; 146.3 ; 134.1,126.9$; $116.2 ; 113.7 ; 113.4 ; 73.7 ; 37.8 ; 24.9 ; 20.8$. MS (FAB), $m / z\left(I_{\text {rel }}, \%\right): 237\left[\mathrm{M}\left({ }^{37} \mathrm{Cl}\right)+\mathrm{H}\right]^{+}(32) ; 235$ $\left[\mathrm{M}\left({ }^{35} \mathrm{Cl}\right)+\mathrm{H}\right]^{+}(100)$.

\section{Anthranilic acid nitrile hydrochloride (13)}

Compound 12 ( $1 \mathrm{~g}, 0.004 \mathrm{~mol})$ was heated in an open solvent-free crucible at $120^{\circ} \mathrm{C}$ for 20 minutes. After cooling, it was purified by boiling $i-\mathrm{PrOH}$. Yield $0.6 \mathrm{~g}(90 \%)$. mp $135-137^{\circ} \mathrm{C}\left(\mathrm{mp} 46-48^{\circ} \mathrm{C}\right.$ (base), $\left.\mathrm{mp} 50^{\circ} \mathrm{C}[13]\right)$, grey powder. ${ }^{1} \mathrm{H}$ NMR spectrum $\left(\mathrm{DMSO}-d_{6}\right), \delta, \mathrm{ppm}(J, \mathrm{~Hz}): 7.36\left(1 \mathrm{H}, \mathrm{d},{ }^{3} J=7.3\right.$, $\mathrm{H} \mathrm{Ar}) ; 7.29\left(1 \mathrm{H}, \mathrm{t},{ }^{3} J=8.3, \mathrm{H} \mathrm{Ar}\right) ; 6.92-7.24(3 \mathrm{H}$, br s, $\left.{ }^{+} \mathrm{NH}_{3}\right) ; 6.79\left(1 \mathrm{H}, \mathrm{d},{ }^{3} J=8.8, \mathrm{H} \mathrm{Ar}\right) ; 6.58(1 \mathrm{H}$, $\mathrm{t},{ }^{3} J=7.3, \mathrm{H} \mathrm{Ar}$ ). ${ }^{13} \mathrm{C}$ NMR spectrum (DMSO- $d_{6}$ ), $\delta$, ppm: $137.7 ; 133.4 ; 132.5 ; 130.5 ; 121.0 ; 118.4$; 104.5. MS (EI), $m / z\left(I_{\mathrm{rel}}, \%\right): 118[\mathrm{M}]^{+}(100)$.

1-Cyclohex-1-en-1-ylquinazolin-4(1H)-one (15)

When cooled with ice, $1.55 \mathrm{~mL}(0.017 \mathrm{~mol})$ $\mathrm{POCl}_{3}$ is slowly dropwise added to $4 \mathrm{~mL}(0.05 \mathrm{~mol})$ DMF. $1 \mathrm{~g}(0.006 \mathrm{~mol})$ of compound 11 was added to the formed Vilsmeier-Haack reagent and stirred for $2 \mathrm{~h}$ at $40^{\circ} \mathrm{C}$. After cooling the reaction mixture to room temperature, the product 15 was poured on ice, neutralized with a solution of soda to an alkaline medium and filtered. Yield $0.88 \mathrm{~g} \mathrm{(65 \% ),} \mathrm{mp} \mathrm{170-}$ $172^{\circ} \mathrm{C}$, white powder. ${ }^{1} \mathrm{H}$ NMR spectrum (DMSO$\left.d_{6}\right), \delta, \operatorname{ppm}(J, \mathrm{~Hz}): 8.14\left(1 \mathrm{H}, \mathrm{d},{ }^{3} J=7.3, \mathrm{H} \mathrm{Ar}\right)$; $8.05(1 \mathrm{H}, \mathrm{s}, \mathrm{CH}) ; 7.85\left(1 \mathrm{H}, \mathrm{t},{ }^{3} J=7.3, \mathrm{H} \mathrm{Ar}\right) ; 7.69$ $\left(1 \mathrm{H}, \mathrm{d},{ }^{3} J=7.8, \mathrm{H} \mathrm{Ar}\right) ; 7.58\left(1 \mathrm{H}, \mathrm{t},{ }^{3} J=7.3, \mathrm{H} \mathrm{Ar}\right)$; $5.65(1 \mathrm{H}, \mathrm{m}, \mathrm{CH}) ; 2.18-2.32\left(4 \mathrm{H}, \mathrm{m}, 2 \mathrm{CH}_{2}\right) ; 1.60-$ $1.77\left(4 \mathrm{H}, \mathrm{m}, 2 \mathrm{CH}_{2}\right)$. MS (FAB), $m / z\left(I_{\mathrm{rel}}, \%\right): 227$ $[\mathrm{M}+\mathrm{H}]^{+}(100)$.

Similarly compound 16 was prepared. (16)

1-Cyclopent-1-en-1-ylquinazolin-4(1H)-one

Yield $0.88 \mathrm{~g}(65 \%), \mathrm{mp} 156-159^{\circ} \mathrm{C}$, white powder. ${ }^{1} \mathrm{H}$ NMR spectrum (DMSO- $\left.d_{6}\right), \delta$, ppm $(J, \mathrm{~Hz}): 8.15\left(1 \mathrm{H}, \mathrm{d},{ }^{3} J=7.2, \mathrm{H} \mathrm{Ar}\right) ; 8.07(1 \mathrm{H}, \mathrm{s}$, $\mathrm{CH}) ; 7.81\left(1 \mathrm{H}, \mathrm{t},{ }^{3} J=7.4, \mathrm{H} \mathrm{Ar}\right) ; 7.70\left(1 \mathrm{H}, \mathrm{d},{ }^{3} \mathrm{~J}=7.8\right.$, $\mathrm{H} \mathrm{Ar}) ; 7.58\left(1 \mathrm{H}, \mathrm{t},{ }^{3} \boldsymbol{J}=7.3, \mathrm{H} \mathrm{Ar}\right) ; 5.61(1 \mathrm{H}, \mathrm{m}$, $\mathrm{CH}) ; 2.22-2.32\left(4 \mathrm{H}, \mathrm{m}, 2 \mathrm{CH}_{2}\right) ; 1.63-1.70(2 \mathrm{H}$, $\left.\mathrm{m}, \mathrm{CH}_{2}\right)$. MS (FAB), $m / z\left(I_{\mathrm{rel}}, \%\right): 213[\mathrm{M}+\mathrm{H}]^{+}$ (100).

1-Cyclopent-1-en-1-yl-6, 7,7-trimethyl-1,5,6,7tetrahydro-4H-pyrrolo [3,4-d /pyrimidin-4-one (18)

When cooled with ice, a Vilsmeier-Haack reagent was prepared with $2.3 \mathrm{~mL}(0.03 \mathrm{~mol})$ of DMF and $0.92 \mathrm{~mL}(0.01)$ of $\mathrm{POCl}_{3} .2 .50 \mathrm{~g}(0.01$ mol) of substance 17 was added to the obtained reagent and left at room temperature for 5-6 days. The reaction mixture was poured onto ice and neutralized with aqueous $\mathrm{NaHCO}_{3}$ solution to an alkaline medium. The resulting solution is extracted with chloroform $(3 \times 20 \mathrm{~mL})$. The combined hoods are dried over sodium sulfate and evaporated on a rotary evaporator. The oily residue is crystallized from benzene. Yield $0.52 \mathrm{~g}(20 \%), \mathrm{mp} 97-100^{\circ} \mathrm{C}$, white powder. ${ }^{1} \mathrm{H}$ NMR spectrum (DMSO- $\left.d_{6}\right), \delta$, ppm $(J, \mathrm{~Hz}): 8.11(1 \mathrm{H}, \mathrm{s}, \mathrm{CH}) ; 6.08-6.13(1 \mathrm{H}, \mathrm{m}, \mathrm{CH})$; $3.39\left(2 \mathrm{H}, \mathrm{s}, 5-\mathrm{CH}_{2}\right) ; 2.25(6 \mathrm{H}, \mathrm{s}, 2 \mathrm{Me}) ; 2.18(3 \mathrm{H}$, $\mathrm{s}, \mathrm{NMe}) ; 1.14-1.25\left(8 \mathrm{H}, \mathrm{m}, 4 \mathrm{CH}_{2}\right) \cdot{ }^{13} \mathrm{C} \mathrm{NMR}$ spectrum (DMSO- $\left.d_{6} / \mathrm{CCl}_{4}\right)$, d, ppm: $165.9 ; 155.2$; $151.3 ; 135.5 ; 131.1 ; 117.9 ; 66.0 ; 53.6 ; 32.6 ; 30.3$; $24.0 ; 21.9 ; 20.3 .{ }^{13} \mathrm{C}$ NMR DEPT-135 spectrum $\left(\mathrm{DMSO}-d_{6} / \mathrm{CCl}_{4}\right), \mathrm{d}, \mathrm{ppm}: 151.3(\mathrm{CH}) ; 131.1(\mathrm{CH})$; 53.6 $\left(\mathrm{CH}_{2}\right) ; 32.6\left(\mathrm{CH}_{3}\right) ; 30.3^{*}\left(\mathrm{CH}_{2}\right) ; 24.0\left(2 \mathrm{CH}_{3}\right)$; 
$21.9^{*}\left(\mathrm{CH}_{2}\right) ; 20.3^{*}\left(\mathrm{CH}_{2}\right)$. ( ${ }^{*}$ stands for signals in antiphase). MS (FAB), $m / z\left(I_{\text {rel }}, \%\right): 260[\mathrm{M}+\mathrm{H}]^{+}$ (55).

X-ray diffraction study of 18 was performed at 298 K by using an "Xcalibur 3" diffractometer. Crystal data are as follows: monoclinic, $\mathrm{C}_{15} \mathrm{H}_{23} \mathrm{~N}_{3} \mathrm{O} \cdot \mathrm{H}_{2} \mathrm{O}, \mathrm{a}=29.257(3) \AA, \mathrm{b}=6.7529(7) \AA$, $\mathrm{c}=16.6468(17) \mathrm{E}, \beta=118.305(3)^{0}, \mathrm{~V}=2895.7(5) \AA^{3}$, $\mathrm{M}_{\mathrm{r}}=277.36, \mathrm{Z}=8$, space group $\mathrm{C} 2 / \mathrm{c}, \mathrm{d}_{\text {calcd }}=1.272 \mathrm{~g}$ $\mathrm{cm}^{-3}, \mu\left(\mathrm{MoK}_{\mathrm{a}}\right)=0.086 \mathrm{~mm}^{-1}, \mathrm{~F}(000)=1200$. Intensities of 5959 (2937 unique, $\mathrm{R}_{\mathrm{int}}=0.062$ ) reflections were measured with a Bruker APEX 2 Duo diffractometer (CCD detector) ( $\mathrm{MoK}_{\alpha}, \mathrm{w}$-scans, $2 \theta_{\max }=52 \cdot 7^{\circ}$ ). Structure was solved by direct method and refined on F2 with Shelx-2013 software [15]. Hydrogen atoms were refined in riding model approximation with $\mathrm{U}_{\mathrm{iso}}=\mathrm{n} \mathrm{U}_{\mathrm{eq}}$ of the carrier atom $(n=1.5$ for the water molecule and methyl groups, $\mathrm{n}=1.2$ for the remaining $\mathrm{H}$-atom). Refinement was converged at $\mathrm{wR}_{2}=0.235$ for all 2937 data $\left(\mathrm{R}_{1}=0.078\right.$ for 1421 reflections with $F>4 \sigma(F), S=0.98)$. Crystallographic data were deposited at the Cambridge Crystallographic Data Center (deposit CCDC 2040412).

\section{REFERENCES}

1. Griess P. Ueber die Einwirkung des Cyans auf Anthranilsaure // Ber. Deut. Chem. Ges. - 1869. - Vol.2. P.415-418.

2. Badolato M., Aiello F., Neamati N. 2,3Dihydroquinazolin-4(1H)-one as a privileged scaffold in drug design // RSC Adv. - 2018. - Vol.8. - P.20894-20921.

3. Rearrangement of $5^{\prime}, 6^{\prime}, 7^{\prime}, 8^{\prime}$-tetrahydro-1" $\mathrm{H}$ spiro(cyclohexane-1,2'-quinazolin)-4'(3'H)-one during the Vilsmeier reaction / Markov V.I., Farat O.K., Varenichenko S.A., Velikaya E.V. // Mendeleev Commun. - 2012. - Vol.22. - P.101102.

4. The Vilsmeier-Haack formylation of 2,3-dihydro-4H1,3-benzoxazin-4-ones and isomeric 1,2-dihydro-4H-3,1benzoxazin-4-ones: an effective approach to functionalized $2 \mathrm{H}-/ 4 \mathrm{H}-\mathrm{Chromenes}$ and Tetrahydroacridines / Farat O.K., Markov V.I., Varenichenko S.A., Dotsenko V.V., Mazepa A.V. // Tetrahedron. - 2015. - Vol.71. - P.5554-5561.

5. Vilsmeier-Haack reagent: an efficient reagent for the transformation of substituted 1,3-naphthoxazines into xanthenetype dyes / Farat O.K., Ananyev I.V., Varenichenko S.A., Tatarets A.L., Markov V.I. // Tetrahedron. - 2019. - Vol.75. No. 19. - P.2832-2842.
6. Novel xanthene push-pull chromophores and luminophores: Synthesis and study of their spectral properties / Farat O.K., Farat S.A., Ananyev I.V., Okovytyy S.I., Tatarets A.L., Markov V.I. // Tetrahedron. - 2017. - Vol.73. - P.7159-7168.

7. Influence of the amidine fragment on spectral properties of xanthene dyes / Farat O.K., Ananyev I.V., Tatarets A.L., Varenichenko S.A., Zaliznaya E.V., Markov V.I. // J. Mol. Struct. - 2021. - Vol.1224. - Article No. 129191.

8. Synthesis, DNA-binding study, and antioxidant activity of 14-aryl-14H-dibenzo[a,j] xanthene derivatives / Ilangovan A., Anandhan K., Prasad K.M., Vijayakumar P., Renganathan R., Ananth D.A., Sivasudha T. // Med. Chem. Res. - 2015. - Vol.24. - P.344-355.

9. Spiroguanidine rhodamines as fluorogenic probes for lysophosphatidic acid / Wang L., Sibrian-Vazquez M., Escobedo J.O., Wang J., Moore R.G., Strongin R.M. // Chem. Commun. 2015. - Vol.51. - P. 1697-1700.

10. Mechanism of wavelength conversion in polystyrene doped with benzoxanthene: emergence of a complex / Nakamura H., Shirakawa Y., Kitamura H., Sato N., Shinji O., Saito K., Takahashi S. // Sci. Rep. - 2013. - Vol.3. - Article No. 2502.

11. Somasekhara S., Dighe V.S., Mukherjee S.L. Derivatives of 1,2,3,4-tetrahydroquinazolin-4-one // Curr. Sci. - 1964. Vol.33. - No. 21. - P.645-646.

12. The study of neurotropic activity of the pyrrolopyrimidin-4-ones rearrangement products under the action of phosphorus oxychloride / Zaliznaya E.V., Varenichenko S.A., Farat O.K., Markov V.I. // J. Org. Pharm. Chem. - 2020. Vol.18. - No. 1. - P.39-44.

13. Reissert A., Grube F. Beitrage Zur Kenntnis des o Amido benzonitrils // Ber. Dtsch. Chem. Ges. - 1909. - Vol.42. No. 3. - P.3710-3721.

14. A novel class of substituted spiro [quinazoline-2,1'cyclohexane] derivatives as effective PPAR-1 inhibitors: molecular modeling, synthesis, cytotoxic and enzyme assay evaluation / Amin K.M., Anwar M.M., Syam Y.M., Khedr M.A., Kamel M.M., Kassem E.M.M. // Acta Pol. Pharm. - 2013. - Vol.70. - No. 4. - P.687-708.

15. Sheldrick G.M. Crystal structure refinement with SHELXL // Acta Crystallogr., Sect. C: Struct. Chem. - 2015. Vol.71. - P.3-8.

Received 27.10.2020 


\section{ПЕРЕГРУПУВАННЯ ЗАМІЩЕНИХ ПІРИМІДИН-4- ОНІВ В УМОВАХ РЕАКЩЇ̈ ВІЛЬСМАЙСРА-ХААКА}

\section{О.К. Фарат, Е.В. Залізна, С.А. Варенииенко, В.І. Марков}

У роботі надано результати дослідження нових перегрупувань чотирьох гетероциклічних систем з варіацією атомів кисню та азоту, зокрема дані про формілювання 2,2-дизаміщених гідрохіназолонів в умовах реакції Вільсмайєра-Хаака. Відкрито нове перегрупування спіропохідних хіназолін-4(3Н)-онів при дії формілюючого реагенту з утворенням прогнозованих 1-циклогекс(пент)-1-ен-1-ілхіназолін-4(1Н)-онів. Пояснено відсутність подібного перегрупування для 2,2-диметил-2,3-дигідрохіназолин-4(1H)-ону. 6', 7', 7'-Триметил-1',5',6',7'-тетрагідроспіро[циклогексан-1,2'-пірроло[3,4- $d]$ піримідин]-4' (3' $H)$-он є структурним аналогом спіропохідних хіназолін-4(3Н)-онів і при взаємодії з реагентом Вільсмайєра-Хаака відбувається аналогічне перегрупування 3 утворенням 1-циклопент-1-ен-1-іл-6,7,7-триметил-1,5,6,7тетрагідро-4H-пірроло[3,4-d]піримідин-4-ону.

Ключові слова: гідрохіназолони, перегрупування, реагент Вільсмайєра-Хаака, імідоіл хлорид, кристалічна структура.

\section{REARRANGEMENT OF SUBSTITUTED PYRIMIDIN-4- ONES UNDER THE VILSMEIER-HAACK REACTION}

O.K. Farat, E.V. Zaliznaya, S.A. Varenichenko *, V.I. Markov Ukrainian State University of Chemical Technology, Dnipro, Ukraine

* e-mail: svetlanavarenichenko@gmail.com

The article describes the result of our study on rearrangements of four heterocyclic systems with variation of oxygen and nitrogen atoms, in particular, the results of formylation of 2,2-disubstituted hydroquinazolones under the conditions of the Vilsmeier-Haack reaction. A new rearrangement of spiro derivatives of quinazolin- $4(3 \mathrm{H})$-ones was discovered under the action of a formylating reagent with the formation of predicted 1-cyclohex(pent)-1-en-1-ylchinazolin-4-(1H)-ones. The absence of this rearrangement for 2,2-dimethyl-2,3-dihydroquinazolin$4(1 \mathrm{H})$-one is explained. 6',7',7'-Trimethyl-1', 5', 6', $7^{\prime}-$ tetrahydrospiro [cyclohexane-1,2'-pyrrolo[3,4-d]pyrimidine]$4^{\prime}\left(3^{\prime \prime} \mathrm{H}\right)$-one is a structural analogue of spiro derivatives of quinazolin-4 $(3 \mathrm{H})$-ones; it undergoes a similar rearrangement with the formation of 1-cyclopent-1-en-1-yl-6,7,7-trimethyl-1,5,6,7tetrahydro-4H-pyrrolo[3,4-d]pyrimidin-4-one when interacting with Vilsmeier-Haack reagent.

Keywords: hydroquinazolones; rearrangement; VilsmeierHaack reagent; imidoyl chloride; crystal structure.

\section{REFERENCES}

1. Griess P. Ueber die Einwirkung des Cyans auf Anthranilsaure. Ber Dtsch Chem Ges. 1869; 2(1): 415-418. doi: 10.1002/cber.186900201180.

2. Badolato M, Aiello F, Neamati N. 2,3-Dihydroquinazolin$4(1 \mathrm{H})$-one as a privileged scaffold in drug design. RSC Adv. 2018; 8: 20894-20921. doi: 10.1039/C8RA02827C.

3. Markov VI, Farat OK, Varenichenko SA, Velikaya EV. Rearrangement of 5',6',7', 8'-tetrahydro- 1 ' $\mathrm{H}$-spiro(cyclohexane$1,2^{\prime}$-quinazolin)-4'(3"H)-one during the Vilsmeier reaction. Mendeleev Commun. 2012; 22: 101-102. doi: 10.1016/j.mencom.2012.03.017.
4. Farat OK, Markov VI, Varenichenko SA, Dotsenko VV, Mazepa AV. The Vilsmeier-Haack formylation of 2,3-dihydro4H-1,3-benzoxazin-4-ones and isomeric 1,2-dihydro-4H-3,1benzoxazin-4-ones: an effective approach to functionalized $2 \mathrm{H}-/ 4 \mathrm{H}-$ chromenes and tetrahydroacridines. Tetrahedron. 2015; 71: 5554-5561. doi: 10.1016/j.tet.2015.06.069.

5. Farat OK, Ananyev IV, Varenichenko SA, Tatarets AL, Markov VI. Vilsmeier-Haack reagent: an efficient reagent for the transformation of substituted 1,3-naphthoxazines into xanthenetype dyes. Tetrahedron. 2019; 75: 2832-2842.

doi: 10.1016/j.tet.2019.04.007.

6. Farat OK, Farat SA, Ananyev IV, Okovytyy SI, Tatarets AL, Markov VI. Novel xanthene push-pull chromophores and luminophores: synthesis and study of their spectral properties. Tetrahedron. 2017; 73: 7159-7168. doi: 10.1016/j.tet.2017.10.027.

7. Farat OK, Ananyev IV, Tatarets AL, Varenichenko SA, Zaliznaya EV, Markov VI. Influence of the amidine fragment on spectral properties of xanthenes dyes. J Mol Struct. 2021; 1224: 129191. doi: 10.1016/j.molstruc.2020.129191.

8. Ilangovan A, Anandhan K, Prasad KM, Vijayakumar P, Renganathan R, Ananth DA, et al. Synthesis, DNA-binding study, and antioxidant activity of 14-aryl-14H-dibenzo[a,j] xanthene derivatives. Med Chem Res. 2015; 24: 344-355.

doi: 10.1007/s00044-014-1124-8.

9. Wang L, Sibrian-Vazquez M, Escobedo JO, Wang J, Moore RG, Strongin RM. Spiroguanidine rhodamines as fluorogenic probes for lysophosphatidic acid. Chem Commun. 2015; 51: 1697-1700. doi: 10.1039/C4CC08818B

10. Nakamura H, Shirakawa Y, Kitamura H, Sato N, Shinji O, Saito K, et al. Mechanism of wavelength conversion in polystyrene doped with benzoxanthene: emergence of a complex. Sci Rep. 2013; 3: 2502. doi: 10.1038/srep02502.

11. Somasekhara S, Dighe VS, Mukherjee SL. Derivatives of 1,2,3,4-tetrahydroquinazolin-4-one. Curr Sci. 1964; 33(21): 645-646.

12. Zaliznaya EV, Varenichenko SA, Farat OK, Markov VI. The study of neurotropic activity of the pyrrolopyrimidin-4-ones rearrangement products under the action of phosphorus oxychloride. J Org Pharm Chem. 2020; 18: 39-44.

doi: 10.24959/ophcj.20.193867.

13. Reissert A, Grube F. Beitrage zur Kenntnis des o-Amido-benzonitrils. Ber Dtsch Chem Ges. 1909; 42(3): 37103721. doi: 10.1002/cber.190904203120.

14. Amin KM, Anwar MM, Syam YM, Khedr MA, Kamel MM, Kassem EM. A novel class of substituted spiro [quinazoline-2,1'-cyclohexane] derivatives as effective PPAR-1 inhibitors: molecular modeling, synthesis, cytotoxic and enzyme assay evaluation. Acta Pol Pharm. 2013; 70(4): 687-708.

15. Sheldrick GM. Crystal structure refinement with SHELXL. Acta Crystallogr Sect C Cryst Struct. 2015; 71: 3-8. doi: 10.1107/S2053229614024218. 